\title{
Burnout
}

\section{Reena George}

${ }^{a}$ MD, DNB, FRCP Edin., Department of Continuing Medical Education, Christian Medical College Vellore, India

Old Easter lilies, leaves wilting, when all around grass gleams, "The quiet womb palms dapple, of Mother Earth trees fruit. and safe sure arms of Father Heaven

One morn, have food enough,"

they were shorn, He said.

chopped, bruised,

Un-knowing, green things, burnt out. un-doing, just being,

"How will they survive?" seasons passed

I asked the gardener. in moons and stars.

"The bread-winner leaves cannot work."

Then a brave shy flower,

"The bulbs will grow,"

He said. a babe in arms, heard the Light, smiled colors bright, and

"Can bulbs grow

Christmas dawned without the leaves on Easter morn.

that fed them?"

Peer Reviewed: Submitted 31 Jan 2021, accepted 19 Feb 2021, published 30 July 2021

Competing Interests: None declared.

Correspondence: Reena George, Christian Medical College, Vellore, India. reena.vellore@gmail.com

Cite this article as: George R. Burnout. Christian Journal for Global Health. July 2021; 8(1):87.

(C) Author. This is an open-access article distributed under the terms of the Creative Commons Attribution License, which permits unrestricted use, distribution, and reproduction in any medium, provided the original author and source are properly cited. To view a copy of the license, visit http://creativecommons.org/licenses/by/4.0/ 